\title{
The Application of Health and Safety Plan in Nigerian Construction Firms
}

\author{
Mansir Dodo \\ Lecturer II, Faculty of Environmental Design, Ahmadu Bello University, Zaria, Nigeria \\ E-Mails: mansirdo14@yahoo.com; ibrokb@yahoo.com; abdulsalamdalhatu@yahoo.com
}

\begin{abstract}
Construction works all over the world pose serious threat to workers and even non-workers. Health and safety in Nigerian construction firms have long been an issue to reckon with due to the several reports of the occurrence of accidents during construction works. This study investigates the extent of application of Health and Safety Plan in construction firms in Nigeria. A purposive sampling technique was used purposely for convenience sake and data was fetched from three cities with equal representation by the aid of a structured questionnaire. Results reveal that even though most firms studied have been in business for over a decade, one quarter of them hardly comply with any Health and Safety Plan during construction. Furthermore, employees are assets but this study reveals that some firms fully in business neither have Health and Safety insurance for their employees nor do some facilitate payment of Health and Safety insurance for their staff. It was concluded that effective Health and Safety practices for employees in Nigeria are yet to be fully appreciated and implemented among construction firms. As such, it is recommended that relevant authorities should checkmate Health and Safety practices in the Nigerian construction industry.
\end{abstract}

KEYWORDS: Employee, Health and Safety Plan, Nigerian construction firms.

\section{BACKGROUND}

Health and Safety is an inevitable aspect of construction due to its nature of being made up of the conglomerations of people from diverse backgrounds and disciplines with each individual`s output determining the level of success to be recorded at each construction stage. According to Mcintosh et al. (2001), construction workers all over the world are three times more likely to be killed and twice as likely to be injured as workers in other occupations. For instance, Hong Kong recorded a total of 3,001 convictions for Health and Safety offences with a total fine of $\$ 17$ million in 1993 . Out of this figure, 1,382 convictions with a total fine of \$1million were related

Accepted for Publication on 31/10/2013. to construction site alone (Nigeria Tribune, 1997). Furthermore, Baldacconi and Santis (2000) assert that the mortal accidents in the field of the constructions in Italy represent 25 percent of the total of the accidents occurring in industry and services. In the United States of America (USA), National Safety Council (NSC) found that construction injuries accounted for nearly 11percent of all work related injuries and more that 30 percent of all fatalities in 2001 (Eppenberger and Haupt, 2003). In 2005, a four-storey building under construction in Port Harcourt collapsed and not less than twenty workers died in the incident barely 24 hours after a similar incident which occurred in Lagos (The Punch, July 2005).

Recognizing the importance of adequate Health and Safety at construction worksites, the European Union enacted the "control of hazard on temporary and mobile 
construction sites" directive that requires member states to adopt national laws to formalize a process to ensure that construction site safety is considered during the construction process (Yakubu and Iyagba, 2011). According to Eurostat (2008), the problem is not that the hazards and risks on construction site are unknown, it is that they are very difficult to control in a constantly changing work environment.

In Nigeria, Health and Safety has not been given the required attention to reduce or prevent hazards and accidents on construction sites, thereby posing serious threats to workers and even non-workers, creating the need for a quick solution for the issue to be addressed. Oresegun (2009) opines that the attempt to determine the impact of Health and Safety on construction and its correlation with project performance, labour performance, labour motivation and safety plan is as a result of non-compliance of the Nigerian construction companies with Health, Safety and Environmental (HSE) regulations. He further asserts that there is no reliable data on accident cases in construction in Nigeria because contractors neither report accidents appropriately nor keep proper records on accidents. This paper seeks to evaluate the extent of application of Health and Safety Plan in construction sites in Nigeria because implementing Health and Safety measures on construction sites in Nigeria must not be seen as an expensive, time consuming or complex task but rather, must be appreciated and applied to improve work practices and help save lives.

\section{HEALTH AND SAFETY PRACTICES}

Health and Safety is an inevitable aspect of construction because a worker will perform his/her duties to the fullest only when he/she is sure that even when an accident occurs he/she will be good taken care of. Okeola (2009) asserts that Health and Safety in construction is all about preventing people from been killed or injured at work or becoming ill through appropriate precaution and providing a satisfactory working environment.

\section{Health and Safety Regulations in Nigeria}

According to Ezenwa (2011), on any construction site, appropriate Health and Safety methods should be considered and used that will reduce or eliminate risk to death or injury. In Nigeria, the first effort in regulating and controlling Health and Safety at work was the Factories Act of 1958, but unfortunately there is lack of provisions for the enforcement of Health and Safety standards in construction industry. This Act was repealed in 1987 and replaced with the Factories Decree No. 16 and Workman's Compensation Decree No. 17. Both were signed into law on June12, 1987, but became effective in 1990. The Federal Ministry of Labour and Productivity is responsible for the enforcement of the safety and welfare regulations in Nigeria.

However, the Ministry charged with the enforcement of these laws has not been effective in identifying violators probably due to inadequate funding as well as lack of basic resources and training. Also, a safety oversight of other enterprises, particularly construction sites and non-factory works, was neglected. The labour decree does not provide workers with the right to remove themselves from dangerous work situations without loss of employment (Nigerian Factories Act, 2002).

\section{Health and Safety Plan}

The preparation and use of Health and Safety Plan on building projects is a major part of production management of building projects. As such, Bamisile (2004) stipulated that the preparation of project Health and Safety Management Plan, among others, must be carried out in the construction of buildings.

Dodo et al. (2011) assert that the Health and Safety Management Plan aims at promoting and maintaining the highest degree of physical, mental and social wellbeing of construction workers. The prevention amongst workers of departures from health caused by their working conditions, the protection of workers in their employment from risks resulting from factors adverse to health, the placing and maintenance of the worker in 
an occupational environment adapted to his physiological and psychological capabilities and, to summarize, the adaptation of work to man and of each man to his job are all aims of the Health and Safety Management Plan.

The main focus of the Health and Safety Management Plan according to the Council of Registered Builders of Nigeria (CORBON) document is on three different objectives:

i. The maintenance and promotion of workers' health and working capacity;

ii. The improvement of working environment and work to become conducive to safety and health; and

iii. The development of work organizations and working cultures in a direction which supports health and safety at work. Doing so also promotes a positive social climate and smooth operation and enhances productivity of the undertakings.

This is in line with assertions by Goetsch (2003) that although one or more people can be given the primary responsibility for coordinating, facilitating and directing a company's safety and health activities, all construction personnel share the responsibility for safety. As such, Griffith and Howarth (2011) argue that the key driver to achieving a safe and healthy working environment is to ensure that health and safety issues are assessed, planned, organized, controlled, monitored, recorded, audited and reviewed in a systematic way.

\section{METHODOLOGY}

\section{Data Sources}

Primary data was fetched using a structured questionnaire in this research. Secondary data sources for this study are: journals, published/unpublished articles, conference scripts, textbooks and the World Wide Web (websites).

\section{Sampling Method, Sample Size and Research Framework \\ This research is exploratory; hence, a}

nonprobability purposive sampling technique was used for this study as is in line with the work of Oresegun (2009). A total of 60 questionnaires (twenty questionnaires each) were distributed to employees (respondents) in construction contracting firms in Kano, Kaduna and Zaria. Such cities were chosen partly for convenience sake but mainly for the hope to systematically improve the research later. The questions were a mixture of open ended and close ended questions. The framework for this study is as presented in Figure 1.

\section{RESULTS}

Out of the 60 questionnaires distributed among the three areas studied, a total of 36 (60\%) were successfully filled and returned. Such return rate is justifiable when compared to the work of Godwin (2008).

\section{Working Experience of Firms}

Four firms had a working experience of between 15 years, 7 firms between 6-10 years, 10 firms between 11-15 years, 8 firms between 16-20 years and 7 firms have a working experience of over 21 years. Results are as depicted in Table 1.

Table 1. Working experience of firms

\begin{tabular}{lcc}
\hline $\begin{array}{l}\text { Experience } \\
\text { (years) }\end{array}$ & Frequency & $\begin{array}{c}\text { Percentage } \\
\mathbf{( \% )}\end{array}$ \\
\hline $1-5$ & 4 & 11.11 \\
$6-10$ & 7 & 19.44 \\
$11-15$ & 10 & 27.78 \\
$16-20$ & 8 & 22.22 \\
21 and above & 7 & 19.44 \\
& & \\
TOTAL & 36 & 100 \\
\hline
\end{tabular}

Source: Field Survey (2013).

\section{Most Frequent Accidents on Site}

Table 2 shows the ranking of the most frequent accidents that occur on site among the responding 
firms. The three most frequent accidents that topped the rank in occurrence are: scaffolding accidents, falls from ladder and stepping or kicking abandoned objects.
The two least frequent accidents are: accidents caused by fire or explosion and compressed gas accidents.

Table 2. Ranking of most frequent accidents on site

\begin{tabular}{clcc}
\hline No. & \multicolumn{1}{c}{ Accidents on site } & Frequency & Rank \\
\hline 1. & Scaffolding accidents & 5 & $1^{\text {st }}$ \\
2. & Lifting equipment failure & 2 & $4^{\text {th }}$ \\
3. & Welding accidents & 2 & $4^{\text {th }}$ \\
4. & Trench collapses & 2 & $4^{\text {th }}$ \\
5. & Stepping or kicking & 3 & $3^{\text {rd }}$ \\
6. & abandoned objects & 2 & $4^{\text {th }}$ \\
7. & Crane accidents & 2 & $4^{\text {th }}$ \\
8. & Forklift truck accidents & 2 & $4^{\text {th }}$ \\
9. & Electric shock injury & 1 & $15^{\text {th }}$ \\
10. & Accident caused by fire or & & $4^{\text {th }}$ \\
11. & Traffic accidents & 2 & $16^{\text {th }}$ \\
12. & Compressed gas accidents & 1 & $2^{\text {nd }}$ \\
13. & Falls from ladders & 4 & $4^{\text {th }}$ \\
14. & Unsafe safety harnesses & 2 & $4^{\text {th }}$ \\
15. & Accidents from faulty & 2 & $4^{\text {th }}$ \\
16. & machinery & & $4^{\text {th }}$ \\
\hline
\end{tabular}

Source: Field Survey (2013).

\section{Availability of Health and Safety Insurance}

Eighteen firms attested to the fact that they have available a Health and Safety Insurance cover for their staff; while 11 do not have any Health and Safety Insurance cover for their staff. Seven firms however did not respond to this question. Results are depicted in Figure 2.

\section{Payment of Health and Safety Insurance}

Of the 18 firms that have available a Health and Safety Insurance cover for their staff, 11 firms (61.11\%) attested to the fact that they facilitate the payment benefits related to Health and Safety insurance for their staff; while 7 firms (38.89\%) attested that they hardly facilitate payment of Health and Safety insurance for their staff. Figure 3 shows such results.

\section{Compliance to Health and Safety Plan/Manual}

Twenty seven firms comply with a Health and Safety Plan during construction; while 9 firms do not comply with a Health and Safety Plan during construction. Results are shown in Figure 4.

\section{SUMMARY OF FINDINGS, CONCLUSION AND FUTURE RESEARCH DIRECTION}

From the results against the backdrop, the following findings may be deduced: 


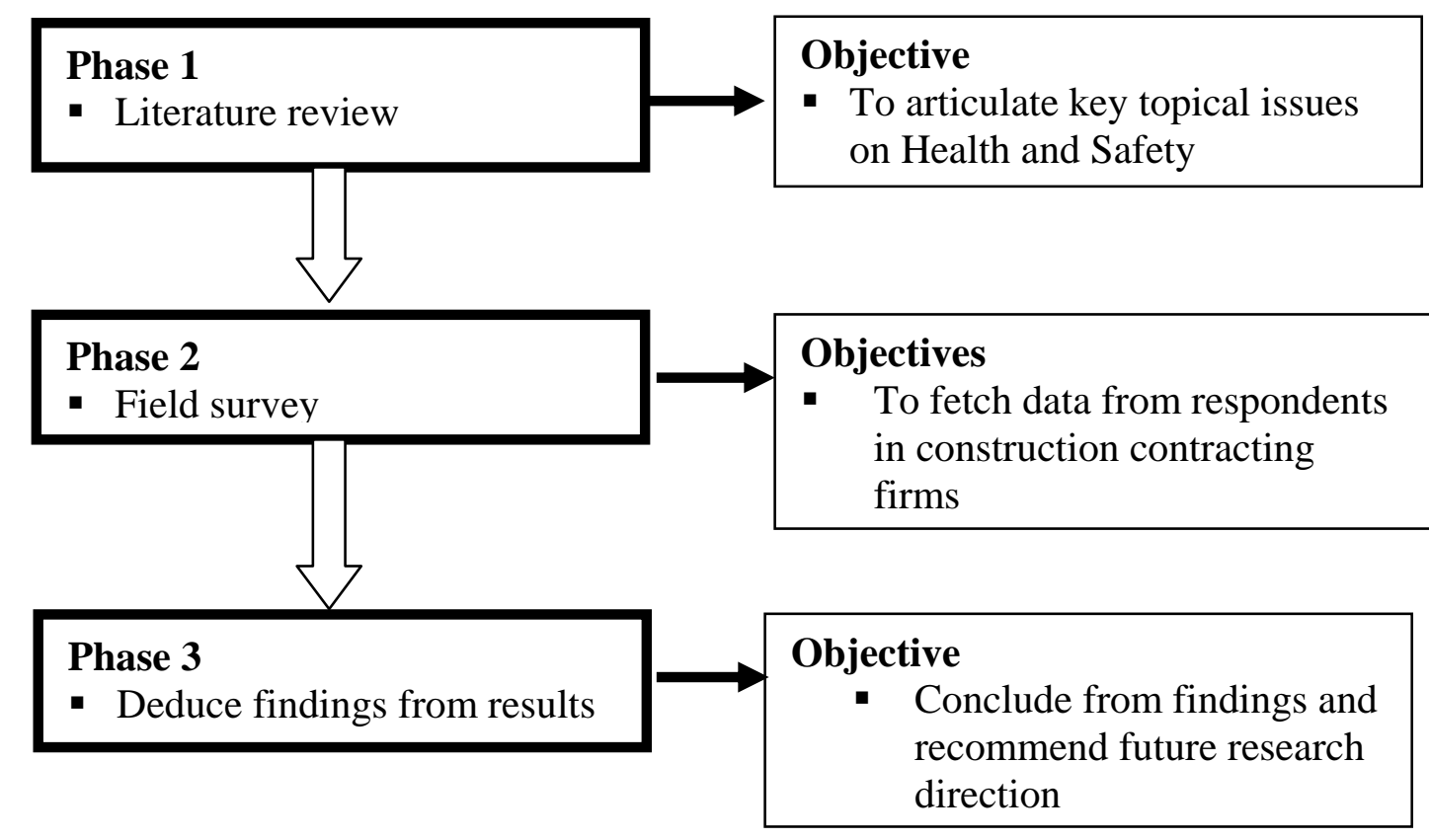

Figure (1): Research framework

Source: Researcher (2013).

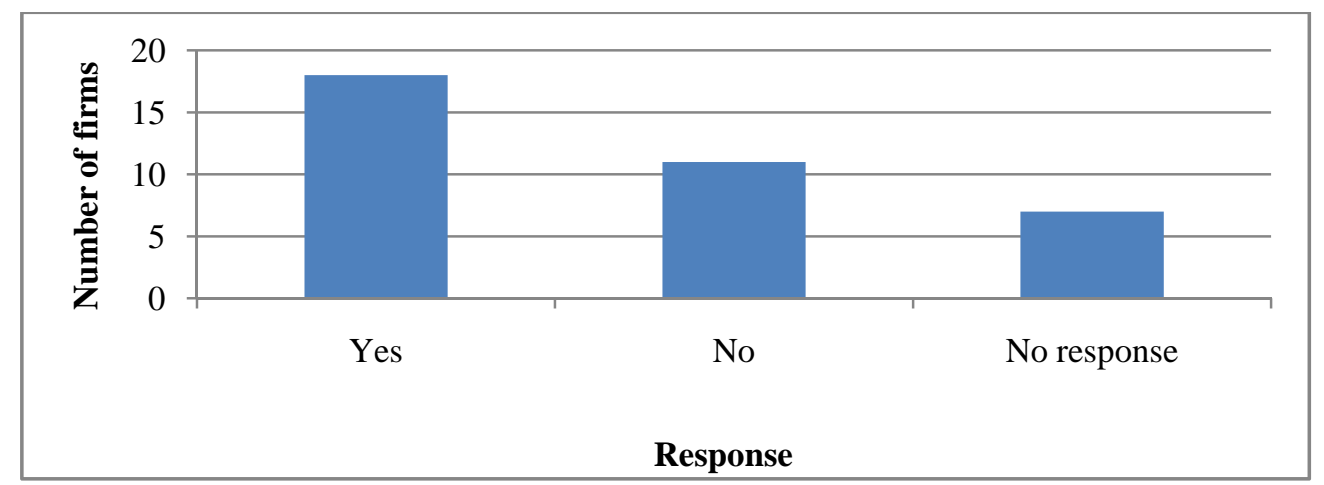

Figure (2): Health and Safety insurance

Source: Field Survey (2013). 


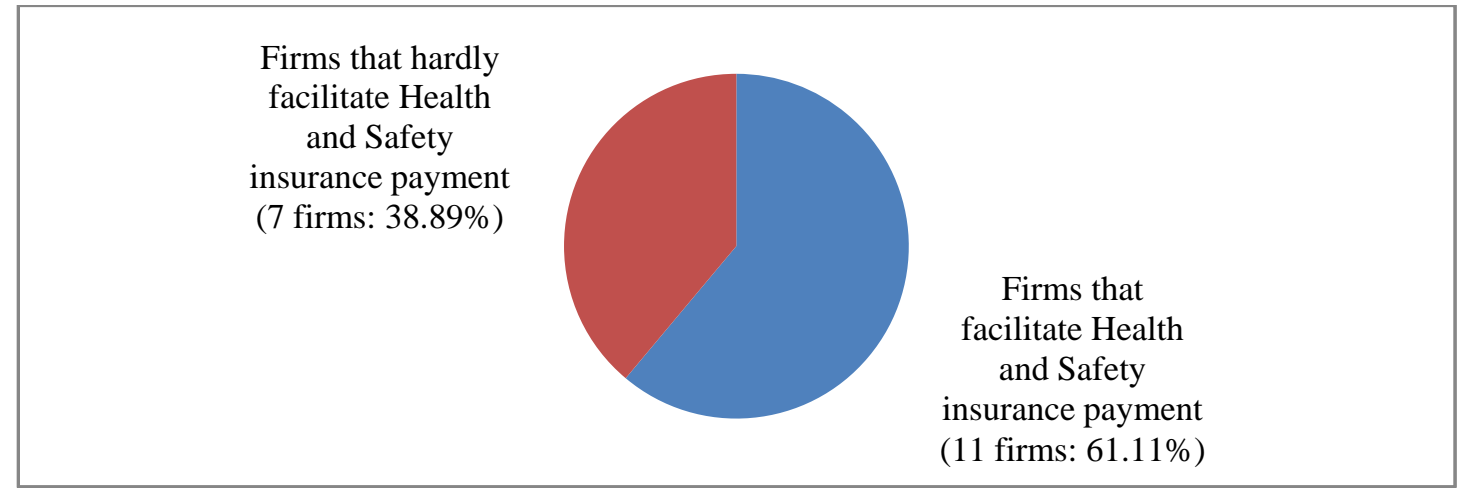

Figure (3): Payment of Health and Safety insurance Source: Field Survey (2013).

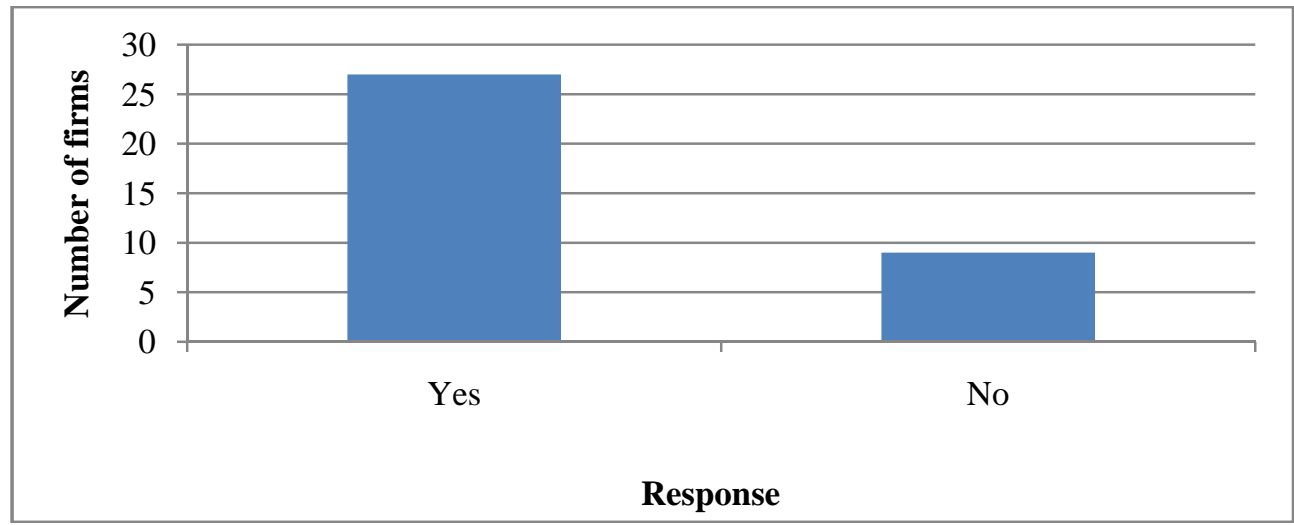

Figure (4): Compliance to Health and Safety Plan Source: Field Survey (2013).

a. More than two-thirds of the responding firms have over one decade of working experience;

b. Even though all the firms studied have experienced one form of accident or the other, some do not have any insurance in place for the Health and Safety of their staff and some do not comply with any form of Health and Safety plan;

c. Of the firms that have a Health and Safety insurance of their staff, more than one third do not facilitate the payment benefits related to Health and Safety insurance for their staff.

It may be concluded that effective Health and Safety practices for employees in Nigeria are yet to be fully appreciated and implemented among construction firms. As such, it may be recommended that appropriate authorities should not only tighten the enforcement of Health and Safety practices but should also foster mechanisms to audit Health and Safety practices in the construction industry for continual improvements because employees are the greatest assets. Further research on this topic may come up with a platform or framework for efficient enforcement and auditing of Health and Safety practices in the Nigerian construction industry. 


\section{REFERENCES}

Abdul Hamid, R., Wan Yusuf, Z., and Singh, B. (2003). "Hazards at Construction Sites", The Proceedings of the $5^{\text {th }}$ Asia-Pacific Structural Engineering and Construction Conference (APSEC 2003), Johor Bahru, Malaysia.

Ahmed, I. (2008). "Adherence to Health and Safety Regulation on Construction Site". Unpublished Project.

Anita, L., and Fellows. (1997). "Research Method of Construction". London: Blackwell Science, Ltd., England.

Baldacconi, A., and Santis, P.D. (2000). "Risk Assessment in Construction Field in Italy". National Institute for Insurance against Injuries at Work. Rome, Italy.

Builders Document 2, Project Health and Safety Plan Template, by CORBON.

Dingsdag, D., and Biggs, H. (2003). "Legislative Frameworks, Compliance and Disability Management in the New South Wales Construction and Coal Mining Industries".

Dodo, Mansir, Buhari M. Manzuma and Andrew M. Stanley. (2011). "Perception of Builders' Documents As Contract Documents and the Imperatives for Their Use". Journal of Environmental Studies, 3 (1\&2), 89103.

Edita, A., and Ryan, D. (2009). "Safety Perception Survey, Yes, You Can Conduct Your Own". ASSE Journal of Professional Safety, Nigeria.

Eppenberger, M., and Haupt, T.C. (2003). "The Older Construction Worker -A Study of Injuries and Their Underlying Causes". CIDB $1^{\text {st }}$ Postgraduate Conference. Port Elizabeth. South Africa.

Ezenwa, A.O. (2011). "A Study of Fatal Injuries in Nigerian Factories". Benin City, Nigeria.

Federal Government of Nigeria. (1990). "The Factory Act of 1990". Federal Government Press, Abuja, Nigeria
Godwin, I. I. (2008). "Health and Safety Management As Correlates of Performance in Nigerian Construction Industry". Journal of Civil Engineering and Management, 14 (4): 277-284.

Griffith and Howarth. (2004). "Construction Health and Safety Management". London: Imperial College.

Health and Safety Executive. (2005). "Respect for PeopleRFP; Code of Good Working Health and Safety Practices". London, England.

HSE Books. (2006). "Health and Safety in Construction, HSG150 ( $3^{\text {rd }}$ ed.)". London, England.

Idoro, G.I. (2007). "A Comparative Evaluation of Health and Safety Performance of Indigenous and Multinational Construction Firms in Nigeria". Construction Research Journal, Lagos, Nigeria.

Idoro, G.I. (2008). "Health and Safety Management Efforts As Correlates of Performance in the Nigerian Construction Industry". Journal of Civil Engineering and Management, Lagos, Nigeria.

National Building Code. (2006).

Nigerian Tribune. (2005). "Occupational Health and Safety (OHS) Assessment in Construction Industry".

Okeola, O. G. (2009). "Occupational Health and Safety (OHS) Assessment in Construction Industry". $1^{\text {st }}$ Annual Civil Engineering Conference, University of Ilorin, Nigeria.

Oresegun, D. (2009). "Health and Safety; the Nigerian Perspective". 2012, www.scribd.com

Piekkala-Fletcher, A. (eds.). (2004). Proceedings of the Third Conference of the Cooperative Research Centre (CRC) for Construction Innovation-Clients Driving Innovation: Benefiting from Innovation, Gold Coast, Australia.

Punch, Monday. (2005). "Occupational Health and Safety (OHS) Assessment in Construction Industry". 